\title{
Microbiological risk infection assessment using QMRA in agriculture systems in Côte d'Ivoire, West Africa
}

\author{
Parfait K. Kouamé • Hung Nguyen-Viet • \\ Kouassi Dongo • Christian Zurbrügg • Jean Biémi • \\ Bassirou Bonfoh
}

Received: 9 March 2017 / Accepted: 5 October 2017 / Published online: 28 October 2017

(C) The Author(s) 2017. This article is an open access publication

\begin{abstract}
Poor wastewater management that results from a lack of appropriate sanitation infrastructure contributes to increasing health risks in urban areas in Côte d'Ivoire. We assessed the health risks associated with the use of wastewater for watering salad destined for human consumption, to help local authorities in developing appropriate risk mitigation measures for Yamoussoukro, the political capital of Côte d'Ivoire. We applied a stochastic approach based on quantitative microbiological risk assessment (QMRA), focusing on wastewater for farming activities and salad consumption at the household level.
\end{abstract}

\section{P. K. Kouamé $\cdot$ K. Dongo · J. Biémi}

Unité de Formation et de Recherche des Sciences de la Terre et des Ressources Minières, UFR-STRM, Université Félix

Houphouët-Boigny, 22 BP 582, Abidjan 22, Côte d'Ivoire

P. K. Kouamé $(\square) \cdot$ K. Dongo • B. Bonfoh

Centre Suisse de Recherches Scientifiques en Côte d'Ivoire, 01 BP 1303, Abidjan, Côte d'Ivoire

e-mail: parfait.kouame@csrs.ci

H. Nguyen-Viet

International Livestock Research Institute (ILRI), Room 301-302, B1 Building, Van Phuc Diplomatic Compound 298 Kim Ma

Street, Ba Dinh District, Hanoi, Vietnam

\section{Zurbrügg}

Eawag, Swiss Federal Institute of Aquatic Science and Technology, Department of Water, Sanitation and Solid Waste for Development, Überlandstrasse 133, 8600 Dübendorf, Switzerland

B. Bonfoh

Swiss Tropical and Public Health Institute, Swiss TPH,

Socinstrasse 57, 4051 Basel, Switzerland
Farming activities rely on a large degree on contaminated water and are conducted without any protection. The QMRA highlights that the poor quality of watering water increased the microbiological risk of the two assessed groups of urban farmers and individual households. The annual risk of infection due to watering wastewater in the city is estimated at 0.01 per person per year (pppy) for Giardia lamblia and 0.2 pppy for Escherichia coli O157:H7. The annual risk from salad consumption is 0.01 pppy for G. lamblia and 0.9 pppy for E. coli O157:H7. Both the annual risks from farming activities and salad consumption were higher than the tolerable standard of risk of $10^{-4}$ pppy as defined by the World Health Organization. There is a need to conduct a risk analysis and a cost-effectiveness study on intervention to improve public health and the livelihoods of the producers which are women in majority in Yamoussoukro.

Keywords QMRA·Health risk - Agriculture system . Wastewater $\cdot$ Surface water Côte d'Ivoire

\section{Introduction}

Poor sanitation management often has a negative impact on the quality of the water that is used for urban agriculture (UA) in developing countries. The sanitation situation in Sub-Saharan Africa continues to be critical, with a high proportion of people practicing open defecation (20\%). Wastewater contains a large range of contaminants from municipal, agricultural and industrial sources. Pathogens originating from this water source 
pose health risks to farmers and their families, communities living in proximity to wastewater irrigation and consumers of wastewater-irrigated crops (Dickin et al. 2016; Hamilton et al. 2006).

UA plays an important role in enhancing and maintaining food security worldwide. Dealing with increasing global urbanization and environmental threats, ensuring food security for poorer populations becomes a critical issue in developing countries. A recent study showed that UA appears to be a main source of household income, facilitates women's contribution to household food availability and provides other benefits such as economic and social advancements (Poulsen et al. 2015). However, although UA practices contribute to food security, at the same time, they increase human and environmental exposure to harmful substances and microorganisms, especially in developing countries. Wastewater used in UA is usually a complex mixture of chemical and microbiological contaminants in which the presence of faecal bacteria is of significant concern (Pavione et al. 2013). In Abidjan, the economical capital of Côte d'Ivoire, an estimated 30 million $\mathrm{m}^{3}$ of wastewater is released each year into the environment without prior treatment (Soro et al. 2010).

The use of wastewater for irrigation is common in most UA settings and represents a potential risk for farmers (Ferrer et al. 2012). Ishii et al. have shown that using wastewater in farming activities has been a key driver of acquiring water and foodborne infections for a long time (Ishii et al. 2014). The increase in fresh vegetable consumption has led to a corresponding rise in the number of foodborne disease outbreaks linked to production (Bichai and Smeets 2013; Coulliette et al. 2013). Diarrhoea is one of the main causes of morbidity due to inadequate sanitation. An estimated 1.7 million people, among whom $90 \%$ are children of less than 5 years of age, die each day from diarrhoeal diseases (Prüss-Ustün et al. 2014). Escherichia coli O157:H7 and Giardia lamblia, two major causatives of diarrhoea, are found in the environment, food and animals and occur with inadequate sanitation or unsafe drinking water. In the Agboville area in southern Côte d'Ivoire, a prevalence of $13.9 \%$ was reported for diarrhoeal infections caused by $G$. lamblia among schoolchildren (Ouattara et al. 2010). Poor wastewater management is observed in all urban areas in Côte d'Ivoire, and is mostly related to the lack of investment in constructing sanitation infrastructures. Because of water scarcity, wastewater is used for irrigating crops in Côte d'Ivoire.
Yamoussoukro, the political and administrative capital of Côte d'Ivoire, has used more than ten lakes for irrigating crops in the last decades. These lakes receive storm water as well as untreated wastewater from anthropogenic activities (Kouamé et al. 2014a; Seidl 2006). Septic tanks constitute up to $90 \%$ of the sanitation facilities in this city, and the resulting faecal sludge is discharged into the lakes. UA activities rely on water from those lakes; therefore, it is unsurprising that the local authorities have reported 3215 and 3444 cases of diarrhoea during the years 2009 and 2010, respectively. Quantitative microbial risk assessment (QMRA) is a probabilistic modelling technique, and it is the main method used to estimate the microbiological risk of infection from exposure to a microorganism (Hamilton et al. 2006).

The current study aimed to assess the microbiological risk from waterborne infections (i.e. E. coli $\mathrm{O} 157: \mathrm{H} 7$ and G. lamblia) linked to the exposure of urban farmers practicing UA and the consumers of raw vegetable in the city of Yamoussoukro.

\section{Material and methods}

\section{Study area}

The city of Yamoussoukro in Côte d'Ivoire was selected as the study area at $6^{\circ} 45^{\prime}-6^{\circ} 50^{\prime}$ north latitude and $5^{\circ}$ $22^{\prime}-5^{\circ} 23^{\prime}$ west longitude (Fig. 1). The urbanized area covers 2720 ha, and a recent census conducted in 2014 estimated the urban population at 207,412 inhabitants (INS 2014). The precipitation is around $1200 \mathrm{~mm} /$ year, and the average annual temperature is $30^{\circ} \mathrm{C}$. Tap water is used throughout the city except in some poor neighbourhoods where water is derived from wells.

Sample collection and laboratory analyses

The sampling and the laboratory analyses were performed according to the guidelines of the US Environmental Protection Agency (EPA) standards (EPA 2010b) during 6 months in Yamoussoukro. A total of 96 specimens of green salad $(n=48)$ and irrigation water $(n=48)$ were sampled and transported to the laboratory on ice for subsequent analyses. During the sample period, four sample points were investigated with an interval of 15 days between each sampling time point, from November 2011 to February 2015 and from 


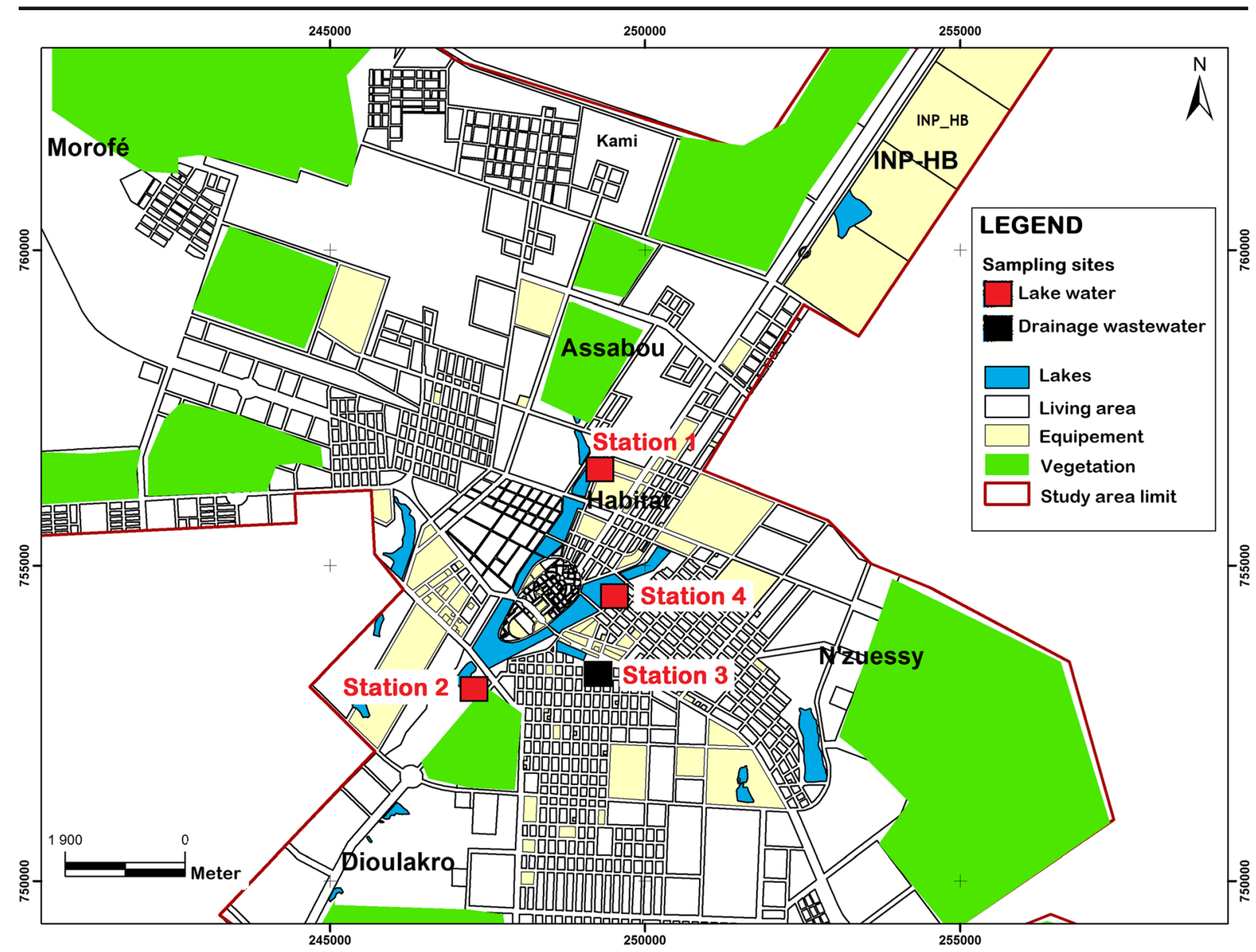

Fig. 1 Study area and sampling sites in Yamoussoukro, Côte d'Ivoire

May 2012 to July 2012. Lake water was sampled in sample stations 1, 2 and 4, while drainage wastewater was at sample point 3. E. coli $\mathrm{O} 157: \mathrm{H} 7$ and G. lamblia were selected as the indicators for faecal contamination.

After transfer to the laboratory, green salad samples were carefully crushed and $20 \mathrm{~g}$ were diluted in water. The analysis of pathogenic E. coli O157:H7 was conducted following EPA standards (EPA 2010b). Both crushed green salad and water samples were distributed into 15 tubes at 3 different concentrations $(1 \times, 2 \times$ and $5 \times)$. After incubation at $37^{\circ} \mathrm{C}$ for $24 \mathrm{~h}$, the presumptive E. coli colonies that appeared in blue salmon colour were sub-cultured on Eosin Methylene Blue Agar for confirmation. Biocard ${ }^{\mathrm{TM}}$ EHEC kits (Ani Biotech Oy, Vantaa, Finland, Ref: 6-001-000) were subsequently used for serological confirmation of the E. coli O157:H7. The "Most Probable Number" of the pathogen was assessed using the US EPA method with the table of Albert Klee (EPA 2010b). G. lamblia cysts were studied and isolated according to the sodium acetate formalin (SAF) technique (AFNOR 2001). After 2-6 h of decantation of the 1-1 crushed diluted green salad samples, the sediment was collected and diluted in $10 \mathrm{ml}$ of SAF solution prior to centrifugation for $500 \times \mathrm{g}$ for $10 \mathrm{~min}$. The obtained precipitate was then mixed with $7 \mathrm{ml}$ of $\mathrm{NaCl}$ solution and $3 \mathrm{ml}$ of ether prior to another round of centrifugation for $500 \times \mathrm{g}$ for $10 \mathrm{~min}$. Debris from the side of the tube was carefully decanted, and a few drops of physiological saline to suspend the remaining sediment were added. The cysts were subsequently identified and counted with an optical microscope equipped with a $\times 50$ magnifier.

Microbiological risk modelling

The QMRA has been conducted as described by Haas et al. (2014). This method follows a four main step process consisting in (i) hazard identification, (ii) 
exposure assessment, (iii) dose-response modelling and (iv) risk characterization.

Hazard identification To predict health risk in this study, we chose to analyse G. lamblia and E. coli O157:H7 which represent two well-known diarrhoeacausing organisms.

Exposure assessment The aim of the exposure assessment in this QMRA was to estimate the concentrations and doses of the selected pathogens to which the affected population might be exposed to. Key parameters measured for the exposure assessment were both pathogen concentrations in green salad and irrigation water (lake water and drainage networks). The percentage of the exposed population, the frequency of exposure, and the quantity of salad consumed per day were assessed by questionnaires. The volume of water ingested and the mass of salad consumed during each type of exposure were estimated from the literature.

Two scenarios were used in the exposure assessment for this study. The first scenario concerned wastewater ingested during urban farming activities, and described the exposure dynamics when practicing UA activities using water of poor quality in Yamoussoukro. Green salad is being watered manually by farmers using contaminated wastewater. For this scenario, activity frequencies, duration and type of protection were investigated by using a questionnaire. The second scenario was related to exposure from salad vegetable consumption of which there is very little information at the population level in Côte d'Ivoire. To implement a QMRA in Yamoussoukro under these conditions, we used data from US EPA reports (EPA 2011) and published papers (EPA 2010a; Forslund et al. 2012). Equation 1 represents the ingested dose of E. coli O157:H7 and G. lamblia.

$D=\left(I_{v} \times M_{c}\right)$

In this equation, $D$ is the ingested dose of pathogens, $I_{v}$ the ingested volume and $M_{c}$ the mean concentration of the targeted pathogens. The exposed population was subsequently estimated consulting the questionnaires from those participants eating salad vegetables. It was assumed that all water sources used for irrigation in the study site have a poor quality.

A cross-sectional survey was used to assess exposure with urban farmers and at the household level including all household members above 14 years of age. Due to the non-invasive and non-intrusive nature of the study and the study questions, informed, oral consent was obtained directly from all participants prior to conducting the survey including for those aged under 18 years.

The household questionnaires were addressed preferably to the female members of the household. A total of 492 households participated in the cross-sectional survey conducted from June 2011 to July 2011. The access to sanitary facilities, clean water sources (tap or wells) and the hygiene conditions (hand and salad washing) were assessed and integrated into the risk model (Table 1). The number of people exposed and the frequency of exposure were also estimated during this process. The sample size was calculated with a precision of 5\% at a 95\% confidence level. Equation 2 represents the sample size calculation method.

$n=N /\left(1+N^{*} e^{2}\right)$

In this equation, $n$ represents the sample size, $N$ the number of inhabitants $(207,412)$ and $e$ the acceptable sampling error $(5 \%)$.

Dose-response models: two equation models of dose-response were used in the current study, including the beta-Poisson model (Mok et al. 2014) used to predict the risk linked to E. coli $\mathrm{O} 157: \mathrm{H} 7$, as described by Eq. 3 .

$P_{\text {inf }}=1-(1+D / \beta)^{-\alpha}$

In this equation, $D$ is the ingestion dose, whereas $\alpha$ and $\beta$ represent the shape parameters $(0.0571$ and $\beta 2.2183$, respectively).

An exponential model was used for assessing the health risk linked to G. lamblia, as presented by Eq. 4 .

$P_{\text {inf }}=1-\exp ^{-r \times D}$

In this equation, $r$ is 0.0199 for G. lamblia (Haas and Eisenberg 2001).

Risk characterization: the risk characterization combined dose-response and exposure information which results from the calculation of the annual infection probability $\left(P_{y}\right)$. The single exposure risk was assessed by performing a Monte Carlo simulation with 10,000 iterations in $\mathrm{R}$ software version 3.2.5 (R Development Core Team, CA, USA). The single exposure risk was assessed using a doseresponse model of each pathogen model, and the exposure results were obtained from the crosssectional surveys. The annual probability of 
Table 1 Input parameters with distributions and statistics for exposure assessment

\begin{tabular}{|c|c|c|c|c|c|}
\hline \multirow[t]{2}{*}{ Model parameter } & \multirow[t]{2}{*}{ Unit } & \multicolumn{3}{|c|}{$\begin{array}{l}\text { Probability distribution function and parameter } \\
\text { statistics }\end{array}$} & \multirow[t]{2}{*}{ Reference } \\
\hline & & Distribution & $\begin{array}{l}\text { Mean/ } \\
\text { maximum }\end{array}$ & $\begin{array}{l}\text { Minimum/S. } \\
\text { deviation }\end{array}$ & \\
\hline Volume of water ingested when farming & $\mathrm{ml} /$ day & Uniform & 10 & 15 & Shuval et al. (1997) \\
\hline $\begin{array}{l}\text { Volume of water captured by green salad } \\
\text { vegetables }\end{array}$ & $\mathrm{ml} / \mathrm{g}$ & normal & 0.108 & 0.019 & Hamilton et al. (2006) \\
\hline Pathogen reduction by washing salad & $\log _{10}$ units & Pert & 1 & 0.2 & $\begin{array}{l}\text { Predmore and } \mathrm{Li} \\
\quad \text { (2011) }\end{array}$ \\
\hline Irrigation frequency & $\begin{array}{l}\text { Days per } \\
\text { year }\end{array}$ & Normal & 243.1 & 4.6 & Surveys (2011) \\
\hline Consumption frequency & $\begin{array}{l}\text { Days per } \\
\text { year }\end{array}$ & Normal & 131.6 & 2.6 & Surveys (2011) \\
\hline Concentration of $E$. coli $O 157: H 7$ in water & $\mathrm{MNP} / 1$ & Log-normal & - & - & Lab. analyses (2012) \\
\hline $\begin{array}{l}\text { Concentration of } E \text {. coli } O 157: H 7 \text { in green } \\
\text { salad }\end{array}$ & $\mathrm{MNP} / 100 \mathrm{~g}$ & Log-normal & - & - & Lab. analyses (2012) \\
\hline Concentration of G. lamblia in water & Cyst/1 & Log-normal & - & - & Lab. analyses (2012) \\
\hline Concentration of G. lamblia in green salad & Cyst $/ 20 \mathrm{~g}$ & Log-normal & - & - & Lab. analyses (2012) \\
\hline Parameter G. lamblia $(\mathrm{r})$ & - & Uniform & 0.0198 & 0.02 & Haas et al. (1999) \\
\hline Parameter E. coli O157:H7 $(\alpha, \beta)$ & - & Uniform & $\alpha=0.373$ & $\beta=39.71$ & Teunis et al. (2008) \\
\hline Mass of green salad consumption & g/person/day & Normal & 26.03 & 30.2 & U.S. EPA (2009) \\
\hline Exposed population & Inhabitants & Normal & - & - & Surveys (2011) \\
\hline
\end{tabular}

infection associated with environmental exposure in this study was determined applying Eq. 5.

$P_{\text {inf } / y}=1-\left(1-P_{\text {inf }}\right)^{n}$

In this equation, $P_{\text {inf } / y}$ represents the annual probability of infection, $P_{\text {inf }}$ the probability of infection for a single exposure to an ingested dose $(D)$ of pathogens and $n$ the number of exposure frequency, expressed in number of days per year.

The risk of infection $\left(P_{\text {inf } / y}\right)$ was subsequently converted into risk of diseases $\left(P_{\mathrm{ill}}\right)$. Equation 6 presents the model of annual risk of diarrhoeal disease.

$P_{\mathrm{ill}}=P_{\mathrm{inf} / y} \times P_{\mathrm{ill} / \mathrm{inf}}$

In this equation, $P_{\mathrm{ill} / \mathrm{inf}}$ is the risk of illness constant $\left(P_{\mathrm{ill} /}\right.$ inf $[E$. coli $]=0.25$ (Howard et al. 2006); $P_{\mathrm{ill} / \mathrm{inf}}$ $[$ G. lamblia $]=0.67$ (Rose et al. 1991)).

Statistical analyses and software

The current QMRA modelling applied a Monte Carlo simulation process. All the input parameters included in the risk model were presented as their probability distribution functions that were generated from random values $(10,000$ iterations) from the data collected, either from microbial analyses or household surveys. The modelling was performed using $\mathrm{R}$ software version 3.0.3 (Development Core Team from Vienna, Austria) with application of the $\mathrm{R}$ package (fitdistrplus) to fit the distribution of pathogen concentrations. The mapping was conducted using ArcGIS 10.1 to present the annual risk at sampling sites.

\section{Results}

Exposed population characteristics

The majority of farmers had no formal education (73.0\%), and was above 21 years of age with an average age of 40 years. Among the farmers, $86.0 \%$ were males and $14.0 \%$ were females. The cross-sectional survey was conducted in 492 households representing 3307 inhabitants. Four main age classes were identified: $0-5,6-10$, $11-15$ and $>15$ years, representing 604 (18.3\%), 509 (15.4\%), $452(13.7 \%)$ and $1742(52.7 \%)$ inhabitants. The sampled population was composed of $74.2 \%$ female 
and $25.8 \%$ male participants. The results showed that $82 \%$ of the population were exposed to health risks due to a lack of hygiene treatment prior to eating green salad.

Exposure patterns in the study area

The results of the exposure cross-sectional survey conducted with 38 farmers revealed two main water sources used for irrigating green salad in the study area. The contaminated lake water and wastewater from drainage networks were used in 54 and 46\%, respectively. Figure 2 represents examples of increased exposure to those contaminated water bodies that may contribute to an increased health risk of green salad consumption in Yamoussoukro. Results indicated that after the harvesting, green salad vegetables were sold to either different markets or hostels inside the city of Yamoussoukro (39\%) or outside the city $(61 \%)$. The results of the household cross-sectional survey suggested different types of hygiene treatment procedures of salad prior to consumption.

They include simple washing $(15.7 \%)$, the use of chlorine $(62.6 \%)$ and the use of alternative treatment methods, such as potassium (1.4\%), vinegar $(0.6 \%)$ and salt and lemon (2.4\%). Only a small percentage of the
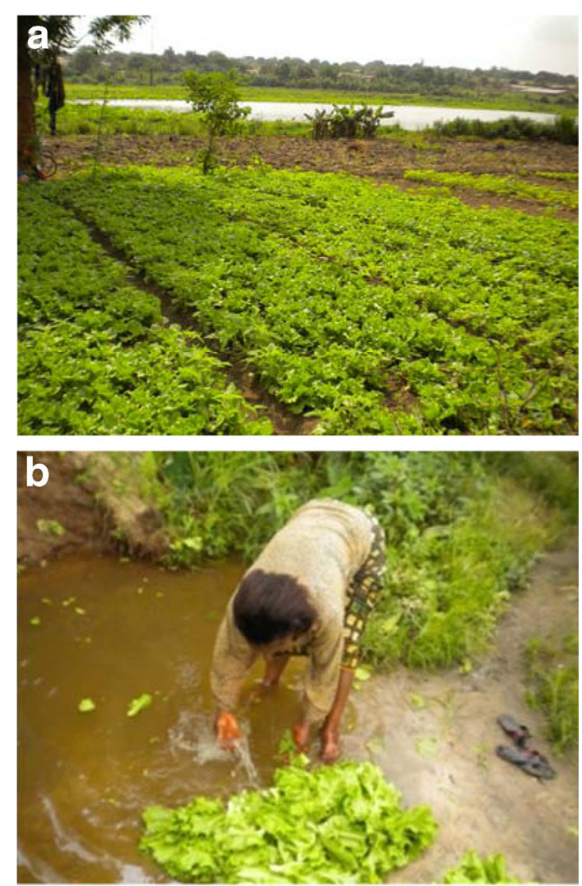

Fig. 2 Exposure related to poor hygienic practices and irrigation water conditions in the study area. a Contaminated lake water used for farming activities in Yamoussoukro. b Exposure routes from poor hygiene of green salads sampled population (1.6\%) was using salad vegetables without any prior hygiene treatment.

Health risks linked to farming activities and salad consumption

Concerning the probability of infection related to G. lamblia, the results showed that station 3 (drainage wastewater) was the biggest source of contamination during the farming activities in the city of Yamoussoukro compared with stations 1, 2 and 4 (lake water). The annual risk linked to the G. lamblia pathogen ranged from 0.0 to 0.36 pppy. However, a higher risk was observed in station 3, with a mean value of 0.04 pppy. The annual risk linked to $E$. coli $\mathrm{O} 157: \mathrm{H} 7$ was high at all four sampling sites, and ranged from $10^{-9}$ to 0.96 pppy. Station 3 demonstrated the highest annual risk (0.18 pppy) for this pathogen. With respect to green salad consumption, the annual risk linked to G. lamblia ranged from 0.0 to 1 pppy, with a mean value estimated at 0.05 pppy. A risk associated with G. lamblia was only demonstrated in station 3 where drainage water is used as source for irrigation. The risk linked to E. coli $\mathrm{O} 157: \mathrm{H} 7$ varied from 0.0 to $1 \mathrm{pppy}$, with a mean value of 0.93 for salad consumption at stations 1, 2, 3 and 4, whereas the maximum risk was observed at station 1 (lake water). The annual risk in this study is presented in Figs. 3 and 4.

Table 2 represents results of $P_{\text {ill }}$ outcomes after using poor-quality water for irrigating green salad in the city of Yamoussoukro. With regard to the risk associated with irrigation water during farming activities, $P_{\text {ill }}$ varied from 0.2 to $4.6 \%$ for $E$. coli $\mathrm{O} 157: \mathrm{H} 7$, and from 0.64 to $2.7 \%$ for $G$. lamblia. The highest $P_{\mathrm{ill}}$ for diarrhoeal diseases was found in station 3. Concerning salad consumption, $P_{\text {ill }}$ ranged from 0.0 to $23.2 \%$ for $E$. coli $\mathrm{O} 157: \mathrm{H} 7$, and from 0.0 to $1.1 \%$, for G. lamblia. Station 1 was more exposed to diarrhoeal diseases according to the $P_{\text {ill }}$ of E. coli $\mathrm{O} 157: \mathrm{H} 7$.

\section{Discussion}

The current study showed that contaminated lake water and wastewater from drainage were used for farming activities in Yamoussoukro at 54 and $46 \%$, respectively. Moreover, it was demonstrated that those water sources were contaminated with E. coli $\mathrm{O} 157: \mathrm{H} 7$ across all sample sites, and that half of the samples sites were, in 


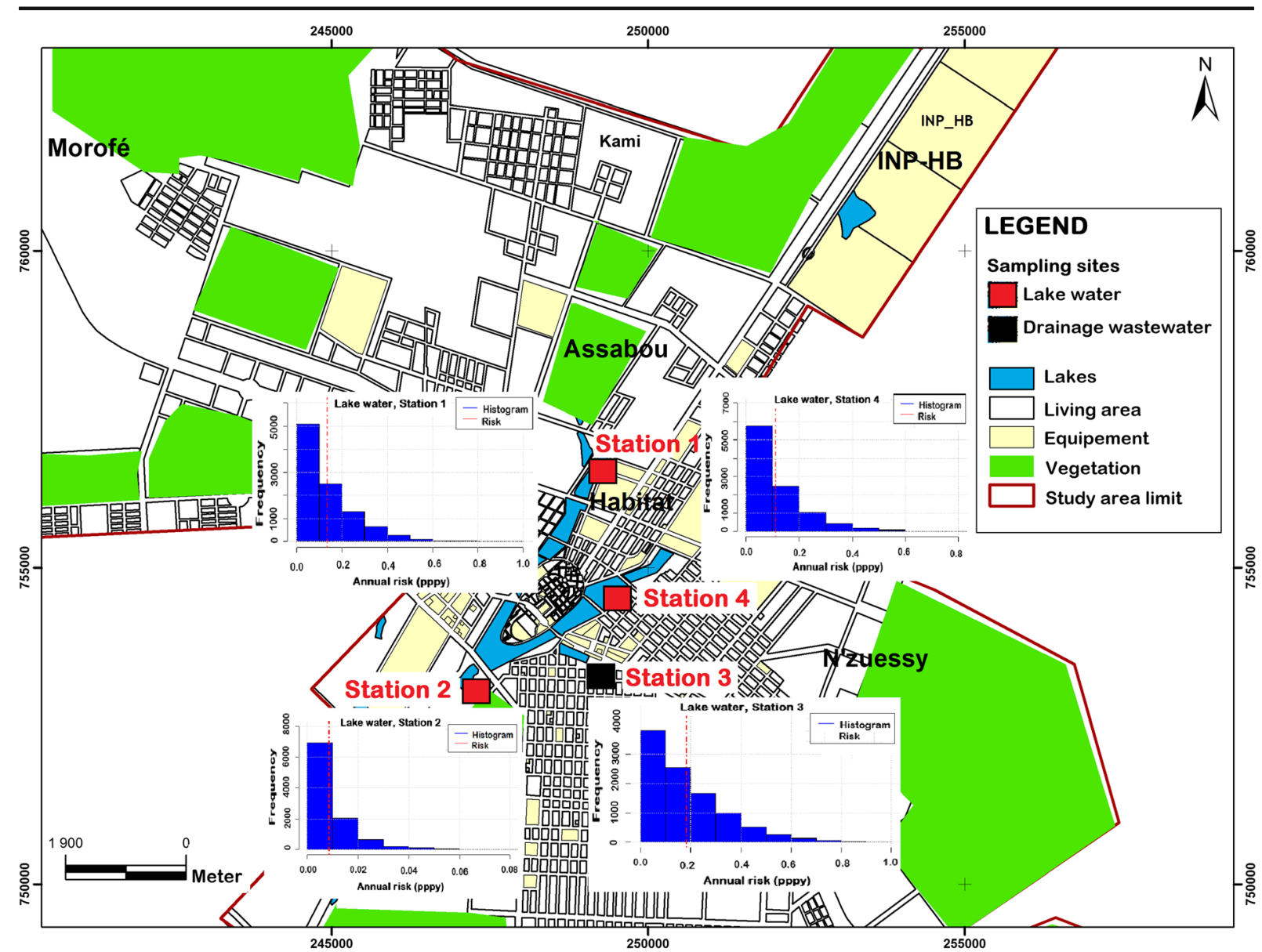

Fig. 3 Map of annual risk linked to E. coli O157:H7 from irrigating with wastewater in Yamoussoukro

addition, contaminated with $G$. lamblia. The United Nations Food and Agriculture Organization has reported that the agricultural sector is the largest user of water and wastewater globally, accounting for approximately $70 \%$ of water use worldwide (FAO 2011), which illustrates the potential scale of this health risk.

The current result in this Côte d'Ivoire-based study showed that the proportion of exposed farmers (46\%) due to the use of wastewater is higher than those observed in equivalent studies in Accra (37\%), but lower than Kenya (53\%) and Zimbabwe (70\%) (Antwi-Agyei et al. 2016). The relevant exposure routes identified during farming activities in Yamoussoukro were use of poor-quality water, the farmer's hygiene precautions and the microbiological quality of post-harvest products. A recent study conducted in Yamoussoukro has demonstrated, indeed, how poor water quality management and wastewater use in urban agriculture can negatively impact on population health (Kouamé et al. 2014b). In the same city, diarrhoea was associated with poor sanitation, whereas households with dry latrines were found to bear a higher risk of infection compared with households that rely on latrines with septic tanks (Kouamé et al. 2014b). However, studies assessing the health risks linked to wastewater and poor sanitation in urban areas in developing countries are not limited to Yamoussoukro or Côte d'Ivoire. In Kenya, Mali and India, it has been shown that the prevalence of diarrhoeal disease transmission for children is related to the number of households that are sharing a latrine (Baker et al. 2016). In Ethiopia, the negative impact of poor sanitation, unsafe water supply and inadequate personal hygiene was demonstrated in the dynamics of diarrhoea occurrence (Gebru et al. 2014). The microbiological contamination in the current study conducted in Yamoussoukro seems to follow a similar pattern when compared with other urban areas in developing countries. 


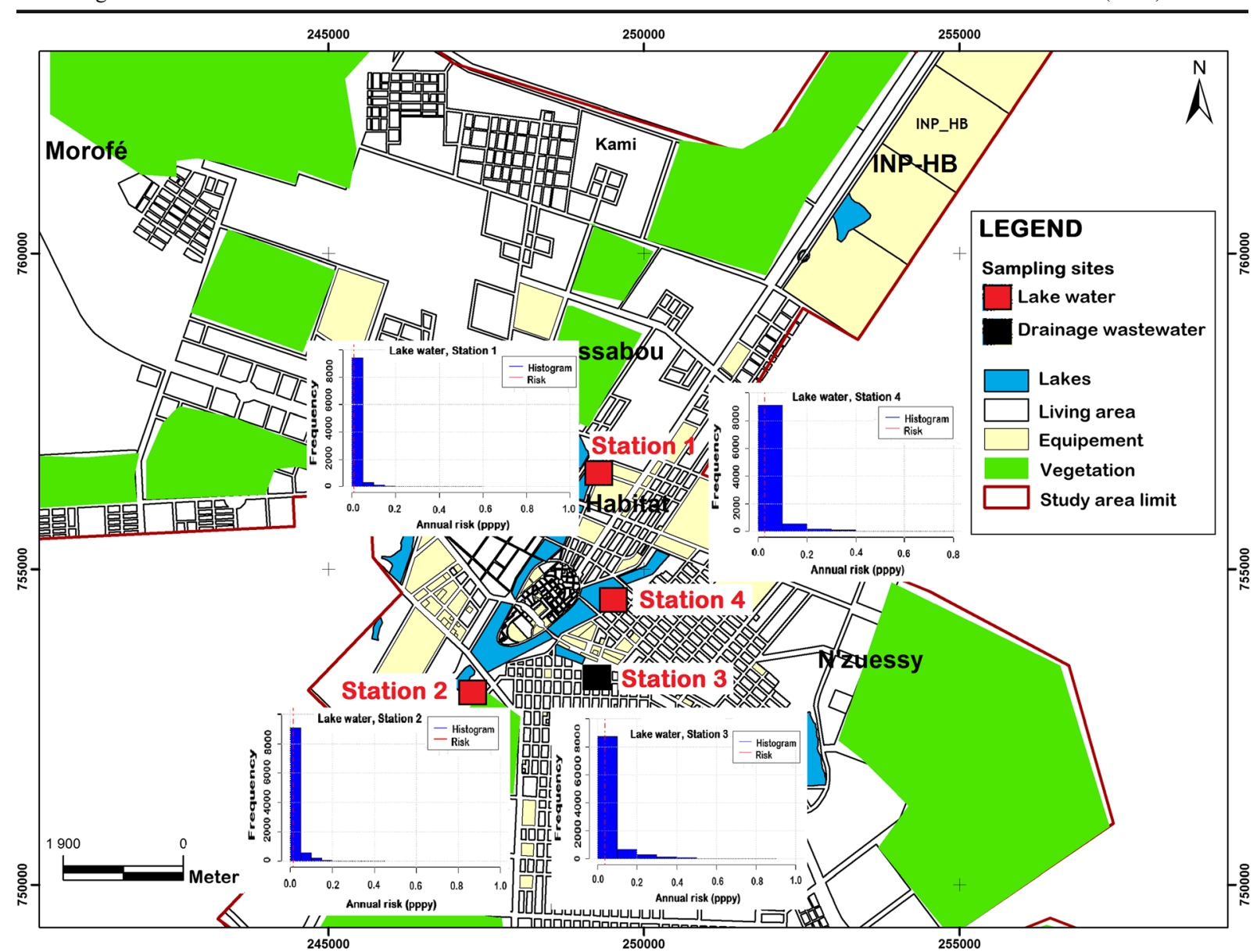

Fig. 4 Map of annual risk linked to G. lamblia from irrigating with wastewater in Yamoussoukro

The improvement of water quality for farming activities is an important aspect in the overall strategy of reducing waterborne and foodborne diseases owing to the close link between the major microbiological contaminations and the use of raw wastewater. In-depth assessment of the association between poor sanitation, hygiene conditions and food security by analyzing the resilience of water, sanitation and hygiene systems to hazards can contribute to the reduction of health risks (Johannessen et al. 2014). The improvement of hygiene during farming activities and green salad harvest could contribute to reduce waterborne diseases in Yamoussoukro.

At the household level, the key exposure routes identified in Yamoussoukro were the lack of hand and green salad washing prior to salad consumption and the presence of poor hygiene conditions. Our study showed that only $15.7 \%$ of all household members assessed practiced simple washing of green salad prior to consumption, and that $62.6 \%$ of this population used chlorine as second treatment. The decontamination of green salad

Table 2 Probability to ill $\left(P_{\mathrm{ill}}\right)$ from E. coli $\mathrm{O} 157: \mathrm{H} 7$ and $G$. lamblia by irrigation and salad consumption

\begin{tabular}{llllll}
\hline Scenarios & Pathogens & 1 & 2 & 3 & 4 \\
\hline 1 (Farming activities) & E. coli O157:H7 & $3.40 \%$ & $2.85 \%$ & $4.57 \%$ & $0.22 \%$ \\
& G. lamblia & $0.64 \%$ & $1.83 \%$ & $2.66 \%$ & $0.95 \%$ \\
2 (Salad consumption) & E. coli $\mathrm{O} 157: \mathrm{H} 7$ & $23.25 \%$ & $0.00 \%$ & $21.25 \%$ & $12.25 \%$ \\
& G. lamblia & $0.00 \%$ & $0.00 \%$ & $1.01 \%$ & $0.00 \%$ \\
\hline
\end{tabular}


by applying hygiene measures is a strong determinant in the reduction of health risks. The microbiological quality of an agricultural food product is influenced by many factors including the type of vegetable, the temperature, humidity and exposure to sunlight during cultivation, the application of irrigation water and post-harvest handling (Antwi-Agyei et al. 2015).

The results of the QMRA confirmed the poor wastewater quality used for irrigation in Yamoussoukro. AU practices increased the microbiological exposure risk of the two targeted groups of individuals - urban farmers and the inhabitants of an average household. Concerning the quality of water for irrigating vegetables, the annual risk is estimated at 0.36 for the pathogen $G$. lamblia and 0.20 pppy for E. coli $\mathrm{O} 157: \mathrm{H} 7$. The probability to ill $\left(P_{\mathrm{ill}}\right)$ from salad consumption is estimated at $1.0 \%$ for G. lamblia and $23.2 \%$ for E. coli O157:H7. The results showed that the annual risks of infection from farming activities and salad vegetable consumption were higher than the tolerable limit of risk defined by the World Health Organization as $10^{-4}$ for irrigating water quality (WHO 2006) and $10^{-6}$ for consumption (Asano 2007; WHO 2006). Similarly high levels of risk linked to E. coli $\mathrm{O} 157: \mathrm{H} 7$ and G. lamblia were found in Abidjan, where the reuse of wastewater and lagoon water was investigated (Yapo et al. 2014). However, the annual risk from $G$. lamblia, identified in Yamoussoukro, was lower compared with findings in Thailand, where the risk of G. lamblia infection from eating vegetables linked to irrigated wastewaters was $100 \%$ (Ferrer et al. 2012).

The $P_{\text {ill }}$ for diarrhoeal diseases related to the use of wastewater in farming activities was found to be very high in Yamoussoukro (estimated at $4.6 \%$ for E. coli O157:H7, and $0.64 \%$ for G. lamblia). As in many cities in West Africa, the use of low-quality wastewater in urban agriculture increases exposure routes to infective agents and, hence, increases the population health risk. The results obtained in Yamoussoukro showed that irrigation water for green salad is contaminated with faecal bacteria as indicated by the presence of E. coli O157:H7 and G. lamblia. These pathogens represented a threat for farmers as well as consumers. Similar observations have been made in a study conducted in Accra (Ghana) by identifying risk factors for product contamination at different entry points of the food chain. After analyzing 500 samples of product and ready-to-eat samples of green salads, the author showed that over $80 \%$ of the product samples were contaminated with E. coli, and that the risk factors identified were irrigation water, storage and hygiene (Antwi-Agyei et al. 2015). Moreover, analysis of different contexts of QMRA implementation in urban settings of developing countries shows that the health risks linked to farming practices could occur by use of both raw wastewater and partially treated wastewater.

The implementation of QMRA in the current setting of Yamoussoukro has shown that the use of raw wastewater for irrigating vegetables represents a potential microbiological health hazard. We demonstrate the importance of the development of mitigation strategies in order to handle health conditions, especially concerning farming activities and hygiene improvements, and offer a base for decision-making.

\section{Conclusions}

This study highlights the exposure routes and the risks of infection with waterborne diseases linked to the poor water quality used for farming activities in the context of water scarcity and food security. Facing this dilemma, farmers have to be sensitized about the potential occupational health threat when using lake waters and wastewaters from drainage networks during UA practices in Yamoussoukro. Equally, the population needs to be educated about hygiene practices before consuming salad vegetables. Innovative water treatment infrastructures have to be implemented in order to treat wastewater pollutants before agricultural use and to optimize the current public health situation.

Acknowledgements We would like to thank the Centre Suisse de Recherches Scientifiques en Côte d'Ivoire (CSRS) and Eawag/ Sandec in Switzerland for the scientific assistance and Dr. Jasmina Saric for editorial support. Also, we are grateful for funding support from the National Centre in Competence of Research (NCCR) North-South programme and the "Programme d'Appui Stratégique à la Recherche Scientifique" (PASRES) in Côte d'Ivoire for this study.

Funding information We are grateful for funding support from the National Centre in Competence of Research (NCCR) NorthSouth programme, the 'Programme d'Appui Stratégique à la Recherche Scientifique' (PASRES) in Côte d'Ivoire and the Swiss government scholarship for developing countries (CFBE) for their funding and training support during this study. The paper was 
prepared with the support of Afrique One-ASPIRE which is funded by DELTAS Africa (107753/A/15/Z).

\section{Compliance with ethical standards}

Conflict of interest The authors declare that they have no conflicts of interest.

Open Access This article is distributed under the terms of the Creative Commons Attribution 4.0 International License (http:// creativecommons.org/licenses/by/4.0/), which permits unrestricted use, distribution, and reproduction in any medium, provided you give appropriate credit to the original author(s) and the source, provide a link to the Creative Commons license, and indicate if changes were made.

\section{References}

AFNOR (2001). Eaux-méthodes d'essai. In : Recueil de normes françaises (6ème édition) - Paris, 1-695.

Antwi-Agyei, P., Cairncross, S., Peasey, A., Price, V., Bruce, J., Baker, K., Moe, C., Ampofo, J., Armah, G., \& Ensink, J. (2015). A farm to fork risk assessment for the use of wastewater in agriculture in Accra, Ghana. PLoS One. https://doi. org/10.1371/journal.pone.0142346.

Antwi-Agyei, P., Peasey, A., Biran, A., Bruce, J., \& Ensink, J. (2016). Risk perceptions of wastewater use for urban agriculture in Accra, Ghana. PLoS One. https://doi.org/10.1371 /journal.pone.0150603.

Asano. (2007). Water reuse: issues, technologies, and applications. New York: McGraw-Hill Professional.

Baker, K. K., et al. (2016). Sanitation and hygiene-specific risk factors for moderate-to-severe diarrhea in young children in the global enteric multicenter study, 2007-2011: case-control study. PLoS Medicine. https://doi.org/10.1371/journal. pmed.1002010.

Bichai, F., \& Smeets, W. S. (2013). Using QMRA-based regulation as a water quality management tool in the water security challenge: experience from the Netherlands and Australia. Water Research. https://doi.org/10.1016/j.watres.2013.09.062.

Coulliette, A. D., Enger, K. S., Weir, M. H., \& Rose, J. B. (2013). Risk reduction assessment of waterborne Salmonella and Vibrio by a chlorine contact disinfectant point-of-use device. International Journal of Hygiene and Environmental Health, 216, 355-361.

Dickin, K. S., Schuster-Wallace, C. J., Qadir, M., \& Pizzacalla, K. (2016). A review of health risks and pathways for exposure to wastewater use in agriculture. Journal of Environmental Health Perspective, 124, 900-909.

EPA (2010a). Quantitative microbial risk assessment to estimate illness in freshwater impacted by agricultural animal sources of fecal contamination, U.S. Env Protection Agency

EPA. (2010b). Standard analytical protocol for Escherichia coli O157:H7 in water. Washington DC: Office of Research and Development.

EPA US (2011) Exposure factors handbook: 2011 edition. EPA/ 600/R-09/052F, Washington DC
FAO. (2011). The state of the world's land and water resources for food and agriculture (SOLAW) - managing systems at risk. New York: Food and Agriculture. The Food and Agriculture Organization of the United Nations and Earthscan.

Ferrer, A., Nguyen, V. H., \& Zinsstag, J. (2012). Quantification of diarrhea risk related to wastewater contact in Thailand. EcoHealth, 9, 49-59.

Forslund, A., et al. (2012). Escherichia coli contamination and health aspects of soil and tomatoes (Solanum lycopersicum L.) subsurface drip irrigated with on-site treated domestic wastewater. Water Research. https://doi.org/10.1016/j. watres.2012.08.011.

Gebru, T., Taha, M., \& Kassahun, W. (2014). Risk factors of diarrhoeal disease in under-five children among health extension model and non-model families in Sheko district rural community, Southwest Ethiopia: Comparative crosssectional study. BMC Public Health. https://doi.org/10.1186 /1471-2458-14-395.

Haas, C., \& Eisenberg, J. (2001). Assessment of risk and risk management for water-related infectious disease. London: IWA Publishing.

Haas, C.N., Rose, J.B., \& Gerba, C.P., (1999). Quantitative Microbial Risk Assessment, Wiley, New York. WHO. Guidelines for the Safe Use of Wastewater, Excreta and Greywater. In WHO, Ed. 2006.

Haas, C. N., Rose, J. B., \& Gerba, C. P. (2014). Quantitative microbial risk assessment (2nd ed.). London: Wiley.

Hamilton, A. J., Stagnitti, F., Premier, R., Boland, A.-M., \& Hale, G. (2006). Quantitative microbial risk assessment models for consumption of raw vegetables irrigated with reclaimed water. Applied and Environmental Microbiology, 72, 3284-3290.

Howard, G., Pedley, S., \& Tibatemwa, S. (2006). Quantitative microbial risk assessment to estimate health risks attributable to water supply: can the technique be applied in developing countries with limited data? Journal of Water and Health, 4, 49-65.

INS 2014 Recensement Général de la Population et de l'Habitat, principaux résultats préliminaires, Côte d'Ivoire

Ishii, S., Nakamura, T., Ozawa, S., Kobayashi, A., Sano, D., \& Okabe, S. (2014). Water quality monitoring and risk assessment by simultaneous multipathogen quantification. Journal of Environmental Science and Technology, 48, 4744- 4749.

Johannessen, A., Rosemarin, A., Thomalla, F., Gerger Swartling, T., Axel Stenström, T., \& Vulturius, G. (2014). Strategies for building resilience to hazards in water, sanitation and hygiene (WASH) systems: the role of public private partnerships. International Journal of Disaster Risk Reduction, 10, 102-115.

Kouamé, N. A., Kouassi, A. M., Gnaboa, R., \& Houenou, P. V. (2014b). Analyse de phénomènes hydrogéologiques dans un bassin versant urbanisé : Cas de la ville de Yamoussoukro (Centre Côte d'Ivoire). Larhyss Journal, 17, 135-154.

Kouamé, P. K., Dongo, K., Nguyen-Viet, H., Zurbrügg, C., Lüthi, C., Hattendorf, J., Utzinger, J., Biémi, J., \& Bonfoh, B. (2014a). Ecohealth approach to urban waste management: exposure to environmental pollutants and health risks in Yamoussoukro, Côte d'Ivoire. International Journal of Environmental Research and Public Health, 11, 1029210309.

Lab. analyses (2012). Data from microbiological analyses, conducted in the laboratory of Centre Suisse de Recherches Scientifiques en Côte d'Ivoire (CSRS), Abidjan. 
Mok, H. F., Barker, S. F., \& Hamilton, A. J. (2014). A probabilistic quantitative microbial risk assessment model of norovirus disease burden from wastewater irrigation of vegetables in Shepparton, Australia. Water Research, 54, 347-362.

Ouattara, M., N'Guéssan, N. A., Yapi, A., \& N'Goran, E. K. (2010). Prevalence and spatial distribution of Entamoeba histolytica/dispar and Giardia lamblia among schoolchildren in Agboville area (Côte d'Ivoire). PLoS Neglected Tropical Diseases. https://doi.org/10.1371/journal.pntd.0000574.

Pavione, D. M. S., Bastos, R. K. X., \& Bevilacqua, P. D. (2013). Quantitative microbial risk assessment applied to irrigation of salad crops with waste stabilization pond effluents. Water Science and Technology, 67, 1208-1215.

Poulsen, M. N., McNab, P. R., Clayton, M. L., \& Neff, R. A. (2015). A systematic review of urban agriculture and food security impacts in low-income countries. Food Policy, 55, 131-146.

Predmore \& Li (2011). Enhanced removal of a human norovirus surrogate from fresh vegetables and fruits by a combination of surfactants and sanitizers. Appl Environ Microbiol, 14, 4829-38. https://doi.org/10.1128/AEM.00174-11.77.

Prüss-Ustün, A., et al. (2014). Burden of disease from inadequate water, sanitation and hygiene in low- and middle-income settings: a retrospective analysis of data from 145 countries. Tropical Medicine \& International Health, 19, 894-905.

Rose, J. B., Haas, C. N., \& Regli, S. (1991). Risk assessment and control of waterborne Giardiasis. American Journal of Public Health, 81, 709-713.
Seidl M (2006). Enjeux et pratiques de l'assainissement en Afrique Sub-Saharienne. Journées Scientifiques de l'Environnement: le citoyen, la ville et l'environnement, France.

Shuval, H., Lampert, Y., \& Fattal B. (1997). Development of a risk assessment approach for evaluating wastewater reuse standards for agriculture. In: Morris, R., Grabow, W. O. K. \& Jofre, J. (eds.). Mallorca, Spain: Elsevier Science Ltd, 32-35.

Soro, N., Ouattara, L., Dongo, K., Kouadio, E. K., Ahoussi, E. K., Soro, G., Ogo, M. S., Savané, I., \& Biémi, J. (2010). Déchets municipaux dans le District d'Abidjan en Côte d'Ivoire : sources potentielles de pollution des eaux souterraines. International Journal of Biological and Chemical Sciences, 4, 2203-2219.

Surveys (2011). Data from the exposure surveys addressed to farmers in the city of Yamoussoukro.

Teunis, P. F., Moe, C.L., Liu, P., Miller, S. E., Lindesmith, L., Baric, R. S., Le Pendu, J., \& Calderon, R. L. (2008). Norwalk virus: how infectious is it? J Med Virol, 80(8), 1468-1476. https://doi.org/10.1002/jmv.21237.

U.S. EPA Exposure Factors Handbook (2009). (External Review Draft). U.S. Environmental Protection Agency, Washington, DC, EPA/600/R-09/052A.

WHO (2006). Who guidelines for the safe use of wastewater, excreta and greywater. Geneva: WHO.

Yapo, R. I., Koné, B., Bonfoh, B., Cissé, G., Zinsstag, J., \& NguyenViet, H. (2014). Quantitative microbial risk assessment related to urban wastewater and lagoon water reuse in Abidjan, Côte d'Ivoire. Journal of Water and Health, 12, 301-309. 